\title{
LAS RUINAS DE BELCHITE: CRÓNICA, MEMORIA, POSMEMORIA Y FANTASMAGORÍA
}

Vicente J. Benet

Universitat Jaume I

ORCID: https://orcid.org/0000-0002-3136-0143

\section{RESUMEN}

Las ruinas de Belchite constituyen un lieu de mémoire fundamental de la Guerra civil española. Las imágenes de la villa devastada han sido frecuentes en el cine, las revistas ilustradas, la televisión y las historietas gráficas desde el final de la guerra hasta la actualidad. El presente artículo ofrece un recorrido sobre el modo en que estas imágenes han sido utilizadas en diversos soportes del audiovisual para elaborar discursos memorísticos en diferentes contextos históricos. Para organizar este recorrido se distinguirán tres fases. La primera se refiere a su configuración por la propaganda franquista y republicana en las crónicas inmediatamente posteriores a la batalla. La segunda, a su instauración como lugar de memoria, mostrando las diversas estrategias de lectura de la guerra desde los años 50 hasta la transición democrática. Finalmente, como recurso en algunas elaboraciones posmemorísticas del presente que permiten una lectura actualizada de la guerra.

Palabras clave: memoria de la guerra civil española, ruinas, propaganda, posmemoria

\section{ABSTRACT}

The ruins of Belchite are an essential lieu de mémoire of the Spanish Civil War. Since the end of the conflict, images of the devastated town have appeared frequently in films, illustrated magazines, comic strips and on television. This article offers an overview of the way in which these images have been used across different audiovisual media to create memory-based accounts of the war in a variety of historical contexts. Three phases are proposed in organising this overview. The first looks at how events were rendered by the Republican, Francoist propaganda machine in the chronicles published in the immediate wake of the fighting. The second examines how Belchite became a place of memorial, and reveals the different ways in which the war was interpreted between the 1950s and the transition to democracy. The third and final phase considers how images of Belchite are used in some presentday, post-memorial interpretations of the war.

Keywords: memory of the Spanish Civil War, ruins, propaganda, postmemory

\section{La concepción de un lieu de mémorie}

De manera semejante al Alcázar de Toledo, o al monumento del Valle de los Caídos, Belchite se instituye como uno de los lugares de memoria paradigmáticos de la guerra civil española y del franquismo. Esta función se establece de una manera muy consistente desde el final de la batalla y se consolida después de su recupe- ración al cabo de unos meses por parte de los sublevados. Efectivamente, una vez retomada la villa por el ejército franquista, sus ruinas pasaron a ser concebidas como monumento que debía integrarse en el programa propagandístico y conmemorativo del campo nacional, proclive a las exaltaciones de corte numantino y a la sublimación del sacrificio heroico. La contemplación 
de las ruinas como metonimia en piedra de los cuerpos humanos destrozados y al mismo tiempo como altar metafórico en el que sus muertes se transubstanciaban para el renacer de una España eterna, fue un elemento importante de dicho discurso propagandístico en el que participaron con artículos y ensayos algunos de sus más representativos intelectuales, como Agustín de Foxá, Edgar Neville o Alfredo Marquerie'1. La celebración de las ruinas se emparentaba también, al fin y al cabo, con usos similares en la Alemania nazi o la Italia fascista, pero tenía precedentes anteriores a los totalitarismos. De este modo, en la época contemporánea había encontrado su punto de partida en algunas villas devastadas durante la primera guerra mundial. Stéphane Michonneau, autor de recientes e imprescindibles estudios sobre las transformaciones del valor memorial de Belchite, establece antecedentes entre los que destaca el entusiasmo de algunos poetas e intelectuales como Gabrielle D'Annunzio o Edmond Rostand por las ruinas de la catedral de Reims, actitud que generó un debate intenso sobre si el edificio debería reconstruirse o no ${ }^{2}$. En cualquier caso, las ruinas constituyeron un referente icónico que funcionó casi inmediatamente como metáfora de la guerra y espacio litúrgico de memoria. $Y$, en este sentido, sus representaciones iconográficas, tanto en el cine como en la fotografía, la pintura e incluso más recientemente la novela gráfica, han recorrido un largo itinerario y una amplia variedad de migraciones por distintos soportes que incluyen desde los primeros reportajes aparecidos en las revistas ilustradas del periodo, o los documentales cinematográficos de urgencia elaborados por los cámaras que seguían a las unidades militares, hasta las reelaboraciones (post) memorísticas más recientes. Este artículo pretende ofrecer un recorrido crítico por algunas de las migraciones más significativas de la iconografía de las ruinas de Belchite desde los postulados de la historia cultural de las imágenes.

La concepción de Belchite como lugar de memoria parte de un discurso mitificador que comienza a forjarse poco después de la ocupación de la villa por el ejército republicano, tras la práctica aniquilación de los defensores franquistas, el 6 de septiembre de 1937. Como señala Ángel Alcalde, después de una serie de ocultamientos e informaciones distorsionadas de la derrota y de unas tensiones políticas que condujeron al relevo del general responsable del cuerpo de Ejército emplazado en Zaragoza por uno de los mandos militares más destacados del momento, el general José Moscardó, se comenzó a plantear casi inmediatamente un proceso de resignificación de la batalla con el fin de ofrecer una lectura heroica y sacrificial de la misma. De este modo, la asociación con la figura de Moscardó, emblema de la defensa del Alcázar de Toledo, era un hecho que inevitablemente ligaba ambos imaginarios para definir un sentido nuevo de lo ocurrido. Siguiendo con esta estrategia de giro interpretativo de la derrota, el propio Franco lanzaba desde Burgos, en las celebraciones del día del Pilar del 12 de octubre de ese mismo año, un mensaje de exaltación de los héroes de Belchite y anunciaba que pensaba emprender gestiones para otorgar a sus defensores la Cruz Laureada de San Fernando 3 . Pero el acto fundacional de este proceso se consumaría con la reconquista del pueblo seis meses más tarde. En marzo de 1938, Franco lanzaba en Belchite la promesa de que construiría un pueblo nuevo, de calles amplias, como compensación al sufrimiento padecido. Las ruinas quedarían, así, como lugar de memoria de un sacrificio para las generaciones futuras.

Pero volvamos a la configuración de las ruinas en relación con la toma por las tropas republicanas. Su fuerza imaginaria se localizaba también en un momento específico de la lucha psicológica y propagandística que acompañó a la estrategia militar de los dos bandos contendientes. La ofensiva lanzada por el Gobierno republicano entre la primavera y el verano de 1937 en Aragón pretendía aliviar, en primer lugar, la presión del ejército sublevado en su avance por el norte mediante una inminente amenaza sobre Zaragoza. Pero buscaba también ofrecer un éxito militar que tuviera resonancia en la retaguardia republicana y en la política exterior del gobierno legítimo. Unido a esto, las operaciones tenían lugar en un momento en el que la maquinaria de propaganda de los dos bandos había alcanzado una madurez y una capacidad de difusión por distintos medios de comunicación que permitía dar la máxima proyección pública a los acontecimientos de la guerra. Los noticiarios cinematográficos, la prensa y las revistas ilustradas nacionales e internacionales, alimentados por los fotorreporteros y opera- 
dores dotados de cámaras ligeras que permitían una proximidad física y temporal a los combates, se encontraba a pleno rendimiento tras el primer año de guerra.

Consecuentemente, en el tratamiento propagandístico de las imágenes de la batalla de Belchite cobraron desde un primero momento un papel relevante los relatos sobre las edificaciones del pueblo. Descritas habitualmente como sofisticados baluartes por la propaganda republicana, se insistía en que habían sido construidos por militares alemanes y convertían a la villa aragonesa en una "fortaleza inexpugnable" 4 . Esta argumentación permitió ofrecer una explicación de la gran cantidad de tiempo y recursos que requirió la toma de un pequeño pueblo de escaso valor estratégico. Pero lo que me interesa subrayar es el papel relevante que asume en estos discursos la consistencia física de las edificaciones y la configuración urbanística de la villa. Su presentación como lugares de avanzada ingeniería militar resultaría poco consistente frente a las imágenes que tomaron los fotógrafos tras su caída. Aunque los defensores franquistas realizaron, como es lógico, numerosas construcciones defensivas, estaban lejos de configurar lo que habitualmente imaginaríamos como una fortaleza inexpugnable. De hecho, los combates se concentraron en las calles y en las casas que fueron tomadas o defendidas hasta el final con enorme sacrificio por ambos bandos. Cobraron particular relevancia sobre todo en algunos edificios concretos, como el Seminario, las iglesias o el Ayuntamiento del pueblo, así como el portal de San Roque que daba entrada a la villa, donde se produjo combate final por parte de los supervivientes franquistas en su intento desesperado por abandonar el pueblo en la última noche de resistencia. Estas edificaciones serán los que aparezcan con más profusión en las revistas que dieron cuenta, nada más acabada la batalla, de las primeras imágenes de las ruinas.

Destaca por ejemplo su tratamiento en la revista Crónica. La portada ${ }^{5}$ muestra la dañada fachada de la iglesia de Belchite: "uno de los últimos focos de resistencia facciosa", precisa el pie de foto. Frente a ella, un grupo de milicianos se dirige hacia la cámara con paso resuelto. El desarrollo de la noticia (escrita por José Quílez y con fotografías Luis Vidal Corella) en las pá-

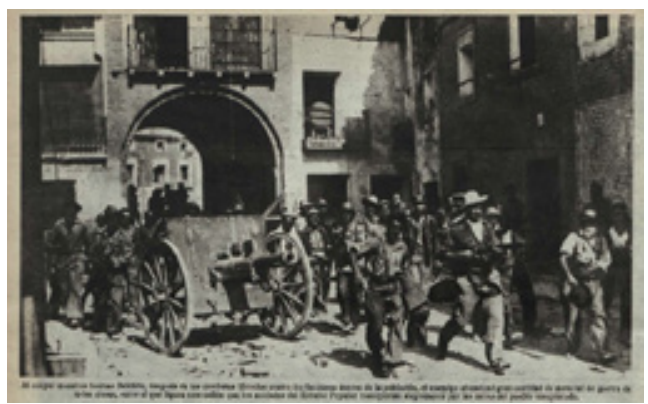

Fig. 1. José Vidal Corella, "Tropas republicanas en Belchite." Crónica, Septiembre 17, 1937

ginas interiores se plantea como un crescendo emocional que comienza con retratos de mujeres ancianas expresando el sufrimiento, en el que asume particular relevancia la figura de campesina telúrica, enjuta y enlutada, típica de la fotografía y el cine documental de los años treinta. Las imágenes posteriores inciden ya en los restos de la batalla. Entre ellas, hay una fotografía que ha sido utilizada en diferentes medios y soportes desde su primera aparición hasta la actualidad (como el documental de Marc Weymuller del que hablaré más adelante) y que muestra a un grupo de soldados republicanos arrastrando un cañón delante del arco de entrada al pueblo mientras avanzan confiados por la calle (fig. 1). El mismo emplazamiento de cámara se escogerá para la ilustración de un artículo de fondo, ya que el pórtico de acceso a la villa adquirió un papel fundamental en la batalla, como acabamos de ver. Bajo esa imagen, la fachada bombardeada del ayuntamiento, "último baluarte de los rebeldes en Belchite", ofrece una dramática huella de la violencia del combate. A continuación, una página compone imágenes de la estación destrozada, un recorrido por fortificaciones y trincheras de los alrededores de Quinto, imágenes de prisioneros del bando rebelde y finalmente una foto del general republicano Pozas charlando con uno de los soldados franquistas capturados bajo la presencia de Quílez Vicente. Debe destacarse que la organización in crescendo del uso de las imágenes en relación con el texto de la noticia se corresponde con estrategias retóricas habituales del momento, revelando una concepción del montaje y la composición de la maqueta de la revista como una progresión en intensidad. Del mismo modo, es significativo el énfasis que cobra 
una figura que se convertirá en central durante la guerra civil: el reportero de guerra no sólo como notario, sino también como protagonista de los acontecimientos.

Las ruinas de Belchite como emblema para concitar el clímax emocional del relato escrito y visual de la propaganda del momento se reproduce en numerosos ejemplos de la prensa durante el mes de septiembre de 1937. Podemos traer a colación, entre muchas otras, la portada del día 14 de $A B C$ (edición de Madrid) que recoge tres imágenes en relación con la ofensiva de Aragón, una corresponde a la toma de Quinto, un pueblo vecino a Belchite, en el que las huellas de la lucha son relativamente anodinas. Contrastando con esto, se pueden observar dos impactantes fotografías de Belchite, el Seminario destruido y a un grupo de milicianos avanzando agazapados por una calle de casas en ruinas, que devuelven al lector a la retórica épica y dramática de la propaganda respublicana. Pero esta no es una la única estrategia a la hora de abordar el tema. Estampa, una revista ilustrada vinculada al Partido Comunista, ofrece una visión que podemos relacionar a primer golpe de vista con un estilo más vanguardista, dependiente de la estética del constructivismo soviético. En este sentido, el nivel de manipulación de la imagen es mayor, buscando el énfasis no tanto en la fuerza dramática de los objetos representados, sino más bien a través de efectos como las composiciones de vertiginosas diagonales o la maquetación de la página. De este modo, sobre la imagen oblicua de la torre de una de las iglesias de Belchite, se recorta la figura de campesinos y niños destacando sobre ellas el de una madre joven mirando con una mezcla de miedo y cansancio hacia el fuera de campo (fig. 2). La crónica, redactada en un estilo novelado y centrado en anécdotas más que en la descripción rigurosa de los hechos, está escrita por J. Izcaray y las fotos son de la agencia de los hermanos Mayo ${ }^{6}$. Es particularmente significativo que, de la serie de diecisiete fotografías que configuran el artículo, sólo una se dedica a las ruinas, concretamente a una calle llena de cascotes y edificios semiderrumbados. El resto nos presenta, fundamentalmente, retratos de campesinos estoicos, de combatientes republicanos y de prisioneros del ejército franquista que

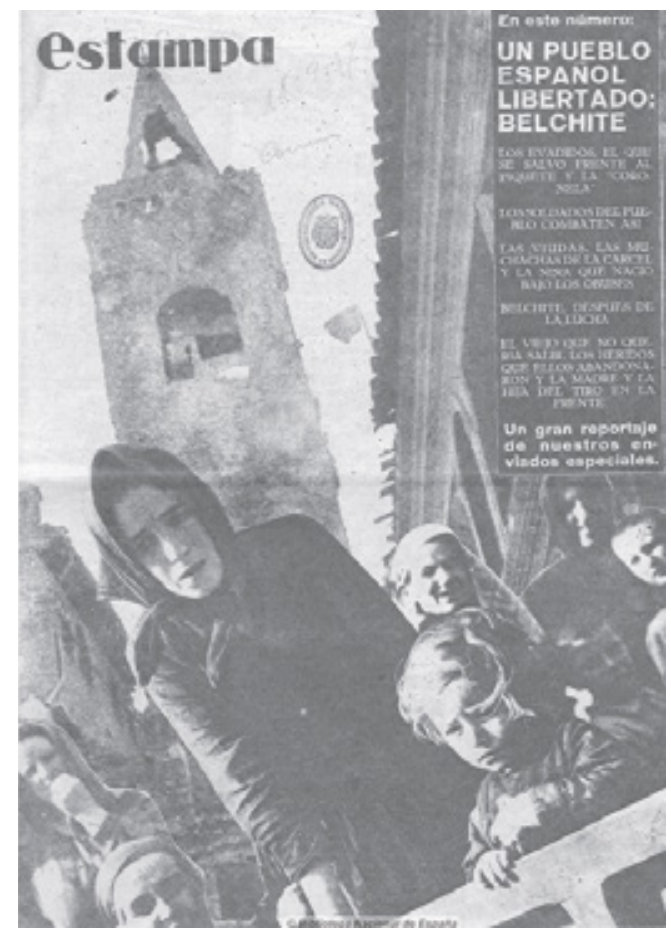

Fig. 2. Agencia Mayo, "Civiles de Belchite tras la batalla." Estampa, Septiembre 18, 1937

nos indican la centralidad del pueblo combatiente para la retórica propagandística comunista. Abundan por tanto imágenes en contrapicado que monumentalizan los cuerpos: niños con el puño levantado, campesinos de caras cuarteadas, ancianas de mirada patética, hileras de prisioneros, heridos en el hospital, instantáneas de combate y sólo una foto en la que aparecen figuras reconocibles. Se trata de Dolores Ibárruri, la Pasionaria, observando los combates con unos prismáticos acompañada del comandante Modesto y del dirigente comunista Uribe. Lo esencial del relato propagandístico comunista, por lo tanto, consiste en convertir a los dirigentes del PCE en síntesis de la lucha del pueblo contra el fascismo. El sufrimiento se expresa en el gesto de esas figuras retratadas que se convierten en alegorías de la España que sufre la agresión del fascismo. Dentro de un sentido tan acotado y dirigido, las ruinas (huella del acontecimiento singular) tienen poco que añadir a un discurso, mucho más abstracto, que apunta hacia un ideal que trasciende el presente. 


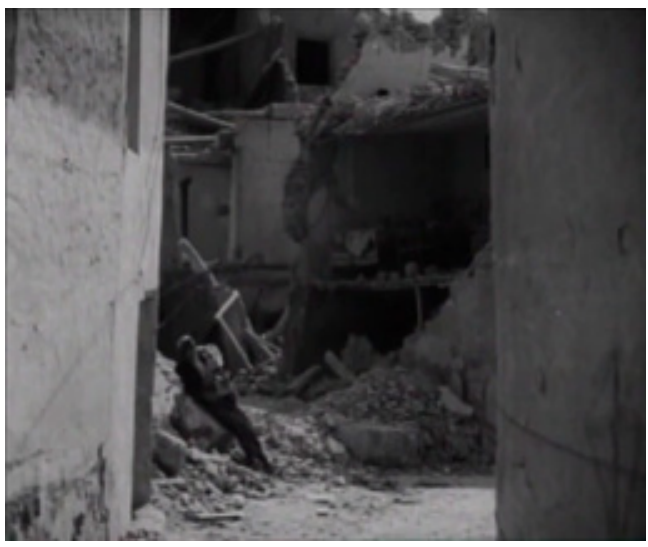

Fig. 3. Félix Marquet, Ruinas de Belchite, imagen de La toma de Teruel, S.I.E. (1938)

En la difusión inmediata del imaginario de las ruinas de Belchite cobrarán también una relevancia particular los noticiarios cinematográficos. En ellos, la dimensión espectacular de la imagen en movimiento exige un dispositivo que organice su sentido y las haga comprensibles al público a través de una narración. El modo primordial en el que la propaganda elaborará esta estrategia será, básicamente, a través de la banda sonora, con una locución ocupada en dirigir de manera precisa la interpretación de las imágenes. Este hecho permitirá que estas mismas imágenes, por espectaculares y vinculadas al acontecimiento que sean, puedan migrar indistintamente por diversos noticiarios o documentales (a veces incluso de los dos bandos enfrentados) y engarzarse sin demasiados problemas en un relato propagandístico determinado. Resulta emblemática en este tipo de trabajo la película La toma de Teruel (1938), compendio de imágenes tomadas por Félix Marquet, uno de los principales operadores cinematográficos vinculados a la producción anarquista, que acompañaron la ofensiva de Aragón, y cuyo material nutrió abundantemente noticiarios y documentales posteriores. Belchite ocupa en esta película el papel de prólogo a lo que será el objeto fundamental del reportaje: la toma de Teruel por el ejército republicano, acontecimiento que se producirá cinco meses más tarde. De este modo, las imágenes muestran columnas de soldados leales que se pierden en el yermo horizonte aragonés o que sonríen animados a la cámara. Tras rápidas escenas de cañones y ametralladoras

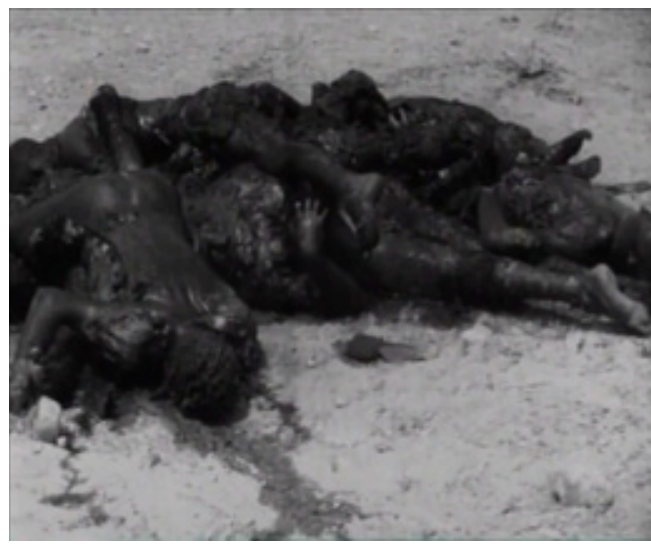

Fig. 4. Félix Marquet, Cadáveres en Belchite, imagen de La toma de Teruel, S.I.E. (1938)

disparando y soldados sumergidos en la lucha, aparecen las ruinas de las calles y algunos edificios emblemáticos de Belchite. Lo que va a llamar la atención de este documental es el carácter descarnado de sus imágenes. Por un lado, las ruinas son mostradas con sobrias panorámicas o planos fijos que se alejan de una retórica formal que las monumentalice o las sublime como metáforas del sacrificio (fig. 3). Más bien al contrario, lejos del énfasis constructivista, es su simplicidad y la impresión de inmediatez y urgencia que transmiten lo que les dota de una fuerza particular. Pero, por otro lado, como gesto que subraya la realidad que hay detrás de la destrucción, la presentación de las ruinas se alterna con impactantes imágenes de cadáveres de hombres y animales caídos en el combate, destacando la de un grupo de figuras calcinadas (fig. 4). Nos encontramos, por tanto, lejos de la visión romántica de la propaganda franquista y entramos en el terreno de la catástrofe que supone la guerra para la humanidad. A su vez, el fragmento del reportaje busca una función más que se deposita en las interpelaciones del locutor: esas imágenes adoptan una función de documento y de prueba de la devastación dirigida hacia los posibles miembros de la Quinta columna que se pueden encontrar en la sala de proyección donde se muestra la película. Presentadas como elemento probatorio, intentan contestar a la contrapropaganda franquista que afirma que el pueblo ha sido entregado por elementos traidores a la causa de los nacionalistas. De este modo, el fin principal de las imágenes es 
desmoralizar a los franquistas que se encuentran en territorio controlado por el gobierno legítimo, haciéndoles ver que la derrota del ejército de Franco es inminente.

No obstante, la recuperación de Belchite por los franquistas vendrá a imponer de nuevo la imagen sublime de las ruinas como muestra del sacificio heroico, de acuerdo con la estrategia diseñada anteriormente. Es interesante en este sentido un libro de Eduardo Fuembuena, redactor de El Heraldo de Aragón, que muestra una colección de imágenes de ruinas junto con un texto plagado de la recurrente retórica sacrifical y numantina de la ideología nacionalista 7 . El libro surge de un reportaje encargado por el periódico zaragozano para acompañar el avance de las tropas franquistas por Aragón en los primeros meses de 1938. Las fotografías de Francisco Martínez Gascón reflejan la función de un reportaje en el que se impone el discurso de la villa-mártir8. Sobre ese discurso se edificaría, una vez retomada la villa por las tropas de Franco, un proyecto conmemorativo que acabaría mostrando algunas contradicciones sintomáticas del régimen en relación con la guerra civil.

\section{La memoria en ruinas}

El acto fundacional de este valor conmemorativo se encuentra en la promesa de Franco, nada más retomar la villa, de construir un pueblo nuevo, bello y de amplias calles para el futuro, dejando las ruinas como espacio para el recuerdo de los hechos acontecidos. El nuevo pueblo fue construido poco a poco por prisioneros republicanos que redimieron parte de sus penas de prisión a través del trabajo forzado. Mientras se edificaba el Belchite nuevo, muchos lugareños siguieron habitando en las zonas del pueblo que no habían sido destruidas por los combates y, de hecho, el pueblo viejo no sería totalmente abandonado hasta bien entrados los años 60 . De todos modos, las ruinas de Belchite suponen un buen modelo para entender el doble discurso sobre el que se asentó la propaganda franquista desde la posguerra. Por un lado (permítaseme sintetizar la idea con su terminología de aquellos momentos) la legitimidad de la Victoria asentada en la sangre derramada por los mártires de la Cruzada. Por otro, la reconstrucción de una

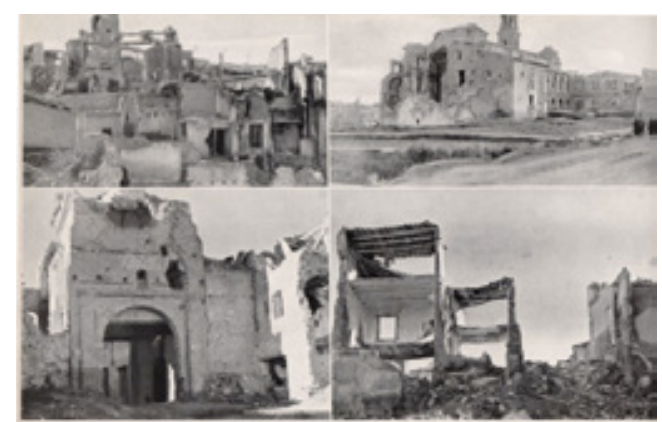

\section{EL SÍMBOLO DE LOS DOS BELCHITES}

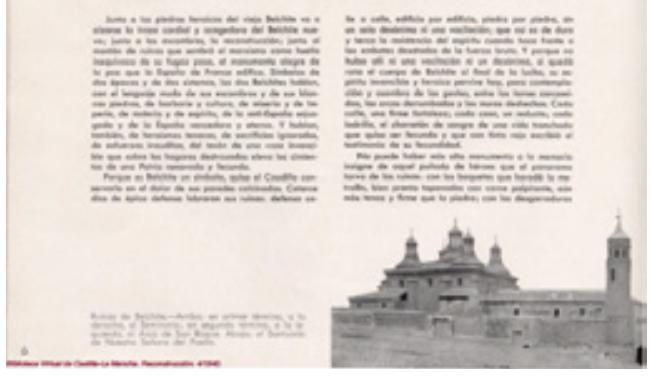

Fig. 5. Pedro Gómez Aparicio, "El símbolo de los dos Belchites." Reconstrucción 1 (1940). Fuente: Biblioteca Virtual de Castilla-La Mancha, publicaciones seriadas (Accedido, 17 de Septiembre de 2018)

España nueva asentada en el trabajo y los valores tradicionales. Este doble discurso aparece manera muy patente en el primer número de la lujosa revista Reconstrucción, publicada por la Dirección General de Regiones Devastadas y Reparaciones, que se abre precisamente con dos artículos sobre Belchite ${ }^{9}$. En el primero de ellos, nos encontramos ante la retórica agresiva de la propaganda de choque, típica de la guerra, que reincide en la sublimación de las ruinas y en su lectura como metáfora de los cuerpos heridos. Sirva como muestra el modo en que el autor nos habla del "cuerpo roto de Belchite" y de la llegada al "...panorama torvo de las ruinas: con los boquetes que horadó la metralla, bien pronto taponados con carne palpitante, aún más tenaz y firme que la piedra, con las desgarraduras de las casas, muñones aún en pie por patente milagro de la gloria; con las mellas profundas de los un tiempo airosos campanarios, en cuyo ápice roto se yergue todavía, aupada hacia las nubes y la eternidad, la invencida promesa de una cruz. Relicario de mártires y de héroes de una mejor 
España, por decisión resuelta del Caudillo conservará Belchite el intacto prestigio del destrozo..."10 Esta transposición antropomorfizada de las ruinas en cuerpos desgarrados es acompañada por un nutrido repertorio de fotografías que dan forma gráfica a la asfixiante retórica del texto (fig. 5). En contraposición, el segundo de los artículos, titulado "La reconstrucción de Belchite" firmado por el arquitecto Antonio Cámara, asume una posición más técnica y menos inflamada, a pesar de la introducción histórica en la que no dejan de aparecer algunos mitos de la lectura del pasado. En un tono más comedido, el texto se acompaña de planos urbanísticos, fotografías mostrando andamiajes y obreros trabajando, apuntando a esa España en reconstrucción que fundamenta el marco ideológico de la revista.

En este díptico que muestra las dos estrategias de la propaganda franquista, resulta particularmente relevante la presencia, como bisagra entre ambos textos, de una página en la que se presenta un fotomontaje con el cuerpo de Franco sobre un paisaje de Belchite. Su figura, en gesto de alocución a las masas, se recorta sobre un enorme boquete en una pared tras el que se divisan las ruinas, imponiéndose como "... una figura tutelar que se interpon[e] entre las ruinas y el espectador."11 (fig. 6) Este gesto retórico incide en la centralidad del líder, ubicado entre la recapitulación de la gesta del pasado (la victoria en la guerra) y la necesaria reconstrucción del presente, funcionando como eje ineludible sobre el que pivota todo el discurso que enlaza la guerra con el porvenir de España. Planteando un punto final a todo este entramado ideológico de la revista, aparecen como punto final del bloque dedicado a Belchite unas fotografías que extienden la idea hacia otras ruinas no menos significativas y que se equiparan a las de la villa aragonesa: el Alcázar de Toledo y el Santuario de la Virgen de la Cabeza.

Sin embargo, después del número de Reconstrucción, la presencia memorialista de las ruinas de Belchite se va a ir esfumando de manera casi absoluta en los medios propagandísticos franquistas. Es prácticamente nula, por ejemplo, en el No-Do, el principal órgano de propaganda dirigida hacia las masas de los primeros años de la posguerra. Es cierto que, como se apuntó anteriormente, la villa no permaneció como un lugar

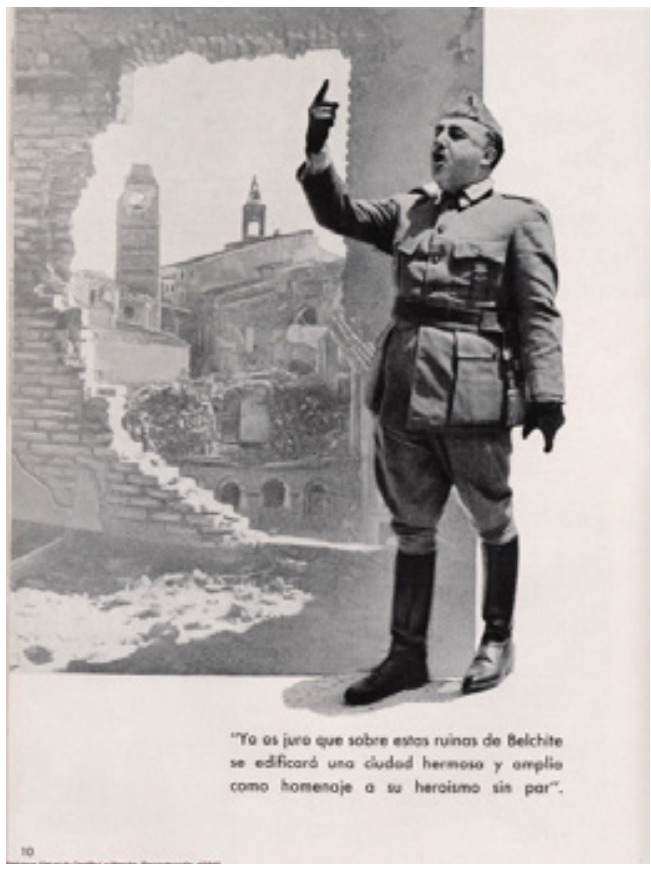

Fig. 6. "Fotomontaje de Franco ante las ruinas de Belchite." Reconstrucción 1 (1940). Fuente: Biblioteca Virtual de CastillaLa Mancha, publicaciones seriadas (Accedido, 17 de Septiembre de 2018)

inaccesible y reservado al culto de los muertos, sino que recuperó en parte su vida habitual con el regreso de numerosos vecinos a las casas que permanecían en pie o que podían ser reparadas. Pero no es difícil deducir que el silenciamiento progresivo de Belchite se corresponde con un cambio de estrategia en la elaboración imaginaria del régimen desde el ámbito de los símbolos, sobre todo después de finalizada la Segunda guerra mundial. El limado de las aristas más relacionables con los fascismos derrotados en 1945 se hizo muy patente en el No-Do y el resto de los medios propagandísticas del régimen. La consecuencia fue el abandono de la retórica agresiva característica del contexto de guerra y la elaboración de un tipo de discurso más sutil, capaz de ir permeando poco a poco en el tejido social para que los individuos acabaran centrándose en sus asuntos, en su trabajo y en el ritmo de la vida cotidiana y se mantuvieran alejados del debate político. Una estrategia propagandística, en suma, no de agitación de las masas sino, como afirman Rafael R. 
Tranche y Vicente Sánchez-Biosca en su excelente historia de No-Do, de desmovilización ${ }^{12}$

El único No-Do que trata de Belchite durante todo este periodo es el número 616 B (con fecha 25 de octubre de 1954). Arranca con cuatro planos de Belchite viejo en los que el locutor hace referencia a los combatientes nacionales que "... lucharon como verdaderos numantinos frente a la superioridad numérica de los marxistas". Esta breve presentación es la única presencia de las ruinas en la noticia, que hasta el final se dedicará a celebrar la inauguración del nuevo pueblo por parte del Caudillo. El hilo principal del discurso se dirigirá, por lo tanto, al presente y al futuro, a la reconstrucción de la nueva España que aunque legitimada por la victoria, apunta hacia procesos de cambio que puedan hacerla asimilable a los otros países del entorno. Consecuentemente, la cámara recorre con insistentes panorámicas las amplias calles y las edificaciones de la nueva villa de Belchite, "limpia y alegre" según la locución, dando cuenta del cumplimiento de la promesa lanzada por Franco. La entrega de títulos de propiedad a algunos de los vecinos por parte del propio Caudillo, la imagen del dictador lanzando un discurso desde el balcón del nuevo ayuntamiento y la comunión con las masas que le aclaman van construyendo un crescendo que culmina con esa fusión de Franco con la multitud enfervorecida, tan habitual en el esquema de las noticias de No-Do. A partir de este punto, podemos convenir en que la poética de las ruinas ya no encajaba de ningún modo con la idea de modernidad y progreso, homologable con la del resto de países occidentales, en la que la administración franquista buscaba su supervivencia. No debemos olvidar que España comenzaba a ser aceptada durante esos años en algunas organizaciones internacionales y apenas un año más tarde entraría en la ONU, abandonando progresivamente el aislamiento de la autarquía y dirigiendo, por tanto, su discurso propagandístico hacia territorios menos comprometidos como el de la promoción turística.

Sólo al final del franquismo las ruinas de Belchite cobrarán de nuevo un papel relevante en algunos modelos que comenzaban a asumir una posición crítica ante la lectura del pasado y sobre todo la memoria de la guerra civil. El primer caso de interés es la película Caudillo (Basilio Martín Patino, 1974) biografía de Franco realizada con material de archivo. Las imágenes de las ruinas de Belchite abren el filme como el indicio más elocuente de la herida de la guerra. También pueden ser interpretadas como la huella paradigmática de la obra de quien va a ser objeto de trabajo de la película, el propio dictador. En cualquier caso, además de servir de prólogo al filme, lo que resulta interesante es el innovador tratamiento cinematográfico por el que opta Patino a la hora de presentar las ruinas. Por supuesto, no hay nada en esas imágenes que quiera buscar la sublimación, el culto, la metáfora sacrificial. Al contrario, el uso del zoom y los encuadres distorsionados por angulaciones extremas, el dinamismo del montaje que incide en los contrastes a la hora de organizar la sucesión de planos, consigue crear una tensión y una sensación de incomodidad que será intensificada por el acompañamiento de la banda sonora. Esta consiste, de entrada, en una cuerda de bajo con un tono percutiente, agresivo, que va a ir convirtiéndose en la melodía de la canción "Puente de los franceses", una célebre adaptación militar de "Los cuatro muleros" que Lorca incluyó en sus grabaciones de las Canciones populares españolas (1931). El tema, sin embargo, se presenta como tocado por una charanga festiva, con instrumentos de metal que suenan de manera distorsionada, generando un efecto de extrañamiento sobre las imágenes de las ruinas que consigue eliminar cualquier posibilidad de evocación emocional. En la parte final de la película se vuelve a Belchite a través de imágenes de archivo entremezcladas con alguna rodada in situ. En este caso, la locución se dirige hacia la descripción de la tragedia de la guerra, aunque no desde la soflama poética del sacrificio, sino con la fría enumeración de cifras de muertos e imágenes de las víctimas. Desde este punto de vista, la idea de Belchite incluso trasciende el acontecimiento concreto de la batalla para apuntar a una idea humanista para la que la guerra es la máxima catástrofe.

Otro caso interesante del retorno memorístico de las ruinas en la fase final del franquismo es el de la película Informe general de Pere Portabella (1976) ${ }^{13}$. En ella, el cineasta catalán tomaba el pulso de un país que estaba a punto de afrontar el proceso de transición meses 
después de la muerte del dictador. Como una crónica en tiempo presente, el filme entrevista a protagonistas políticos del momento, algunos de ellos todavía en la clandestinidad, estableciendo al mismo tiempo una reflexión crítica sobre una dictadura en proceso de desmoronamiento. De este régimen quedan algunas presencias espectrales que puntúan de manera sistemática el desarrollo de la primera parte de la película y la dotan de una estructura pensada a través de contrapesos conceptuales entre pasado y presente que afloran desde el propio arranque del filme, con la presencia inquietante del monasterio del Valle de los Caídos. En otra escena igualmente fantasmagórica, la cámara recorre las salas del Palacio del Pardo y se recrea en algunos indicios de la vida doméstica del dictador. La presencia de las ruinas de Belchite va a cumplir un papel semejante. De acuerdo con la estructura del filme, se emplaza entre dos escenas: una conversación de dos exiliados, José Prat y Anselmo Carretero, que evocan el sufrimiento y la desubicación presente de los expatriados mientras pasean por un parque otoñal y una entrevista al anciano líder derechista José María Gil Robles, quien especula sobre las posibilidades de un cambio democrático en España. Ubicadas por lo tanto entre figuras del pasado cuyas biografías han quedado ancladas en la guerra, las ruinas de Belchite emergen de nuevo como un espacio en el que se abisman las emociones cuando se moviliza la memoria para traer al presente el trauma del pasado. De un modo comparable al tratamiento de Patino, Portabella plantea su puesta en imágenes de las ruinas con una cámara en movimiento constante que recorre los espacios derruidos, las casas desmoronadas, penetrando por el portal de la villa, recorriendo la calle principal, irrumpiendo entre los muros de la iglesia. De nuevo, la banda sonora de Carles Santos apoya ese recorrido vertiginoso, casi delirante, con una música tensa y obsesiva, que resalta el carácter traumático de las ruinas.

Un poco posterior a la película de Portabella es un cortometraje de César Fernández Ardavín titulado Belchite (1982). Los títulos de apertura y cierre utilizan dos grabados de los Desastres de la guerra de Goya, un referente utilizado a menudo en la iconografía de la guerra civil ${ }^{14}$. En cierto modo, el filme parece recuperar la visión sublime de las ruinas que había propugnado la propaganda franquista en un primer momento. De este modo, se suceden los planos estetizantes, los contraluces dramáticos, la textura de las piedras sobre la luz oblícua del amanecer o del atardecer, las composiciones rebuscadas, realzando de manera dramática (y completamente diferente a los dos ejemplos anteriores) el potencial evocador y emocional de las imágenes. Aunque la retórica empleada desde la locución es algo más contenida que en los tiempos de guerra, no deja de ser clara en sus intenciones. Comenzando con un recorrido histórico que se remonta a los íberos, acaba en los hechos de la guerra civil afirmando que su "heroica defensa permitió a Franco parar al ejército rojo, estabilizando el frente el 13 de Octubre en Fuentes de Ebro". Mientras se mantiene este discurso, se escucha de fondo una alegre música de jota, pero esta va dando paso a sonidos de balas. Finalmente, el locutor pedirá un padrenuestro "...por esas tus gentes aragonesas, raza dura, que siempre fue puntual a la cita con la historia". En la banda sonora después de un breve lapso de silencio, aparece una corneta y después una banda militar interpretando el toque de oración por los caídos. Panorámicas y planos con el sol poniente nos parecen devolver a un discurso arcaizante, nostálgico, de un pasado que está a punto de ser barrido por el viento de la historia.

\section{De la posmemoria a la fantasmagoría}

Como podemos observar, los avatares de las ruinas de Belchite como motivo iconográfico han sido procelosos desde la consolidación de la democracia en España. Podemos observar mutaciones que afectan a sus dos características esenciales. Primero a la propia configuración física de las ruinas, puesto que no dejaron de producirse reconstrucciones y tareas de mantenimiento desde recién acabada la guerra hasta la actualidad, sobre todo en el presente siglo, para adecuarlas a las demandas de los cada vez más numerosos curiosos y turistas que las visitan. Por otro lado, a sus diversos procesos de resignificación que hacían ya inviable en la sociedad democrática la función conmemorativa planeada en un principio por la propaganda franquista, un fenómeno que afecta a muchos lugares de memoria de la guerra civil y que dan lugar, por utilizar la expresión de 
Ricard Vinyes, a un paisaje de "signos sin gramática". ${ }^{15}$

Las adaptaciones de su posible función como reflejo del trauma de la guerra en general, o la posibilidad de hacer de ellas un museo para la paz, o su vinculación a la protección del patrimonio mudéjar o, finalmente, su posible incorporación a una posible ruta de dark tourism de la guerra civil, ofrecen una panoplia de opciones sobre su papel en el presente tan variopinta como difícil de consolidar ${ }^{16}$. Igualmente, hay que hacer mención a que, desde finales de los años ochenta, las ruinas de Belchite empezaron a aparecer como decorado de numerosas producciones cinematográficas, televisivas e incluso de videojuegos, convirtiéndose en un espacio moldeable para los imaginarios más dispares, que abarcan en sus extremos desde la fantasía barroca de las Aventuras del Barón de Münchausen (Terry Gilliam, 1987) hasta el filme pornográfico Mundo perro, (Roberto Valtueña, 2008) pasando por varias películas célebres sobre la guerra civil. Mundo perro, expresión máxima de la desacralización del lugar, obligó al ayuntamiento de la villa a ser mucho más vigilante en la concesión de permisos de rodaje $^{17}$, pero esto no ha podido detener el uso de las ruinas para todo tipo de formatos en los que nada queda de lo que pudieron simbolizar, no sólo en relación con la guerra, sino también con la memoria del franquismo. Convertidas en set para fantasmagorías varias, algunos programas de televisión especializados en psicofonías y fenómenos paranormales han acudido al lugar de vez en cuando para proponer estrambóticas conexiones con el más allá.

En cualquier caso, las ruinas de Belchite han vuelto a concitar la atención de productos culturales que se ubican en el terreno de la posmemoria, sobre todo en relatos biográficos de hijos o nietos de aquellos que vivieron los hechos y que permiten establecer un vínculo con el trauma desde el recuerdo familiar mediante un trabajo "imaginativo, creativo y de proyección... [a través del cual] los sucesos del pasado hacen sentir sus efectos en el presente." ${ }^{18}$ Dos producciones recientes de innegable interés destacan en este sentido para establecer un discurso creativo complejo sobre el valor de la posmemoria desde la lectura familiar. La primera es una novela gráfica de Sento Llobell basada en los recuerdos de guerra del doctor Pablo Uriel. La segunda, un filme documental realizado por Marc Weymuller que ofrece una interesante reflexión formal sobre el modo de abordar la memoria a partir del testimonio de los descendientes de los testigos de la batalla y la reconstrucción de Belchite.

Efectivamente, desde hace algunos años han aparecido varias novelas gráficas de enorme interés sobre la guerra civil que encajarían dentro de la corriente de la posmemoria ${ }^{19}$. Realizadas sobre todo por hijos o nietos de protagonistas del conflicto, suelen compaginar el material documental con estrategias narrativas que permiten al lector una conexión emocional muy peculiar con la experiencia transmitida por sus protagonistas. Su valor se asienta, en parte, en la proyección inherente al pacto autobiográfico, pero también en la peculiar relación con la figura paterna o incluso materna asentada en los intercambios simbólicos de don y contradon, extendibles a la mayoría de las experiencias familiares y normalmente realzada por el tono narrativo que asumen estas novelas gráficas ${ }^{20}$.

El cómic de Sento Llobell constituye, probablemente, el caso más destacado de elaboración posmemorística en relación con los imaginarios de Belchite. La trama narrativa del libro se construye a partir de las memorias del protagonista reflejadas en el libro No se fusila en domingo ${ }^{22}$. Pablo Uriel, un joven médico recién licenciado, es sorprendido por el alzamiento militar mientras se encuentra sustituyendo por vacaciones al médico titular de un pueblo de Logroño. De vuelta a Zaragoza, es incorporado a las filas nacionales a pesar de sus simpatías republicanas. Resultando sospechoso por ese motivo, es encarcelado en una prisión militar donde vive la angustia de los fusilamientos constantes y del terror que imponen las autoridades franquistas. Finalmente es liberado después de arduas gestiones de la familia $y$, ante el temor de volver a ser represaliado, decide presentarse voluntario al frente, donde supone que estará más seguro. Su destino es una compañía emplazada en los entornos de Belchite donde consigue alcanzar el grado de alférez. La vida cotidiana en las trincheras está salpicada de situaciones variopintas que reflejan lo mejor y a lo peor de la naturaleza humana. 


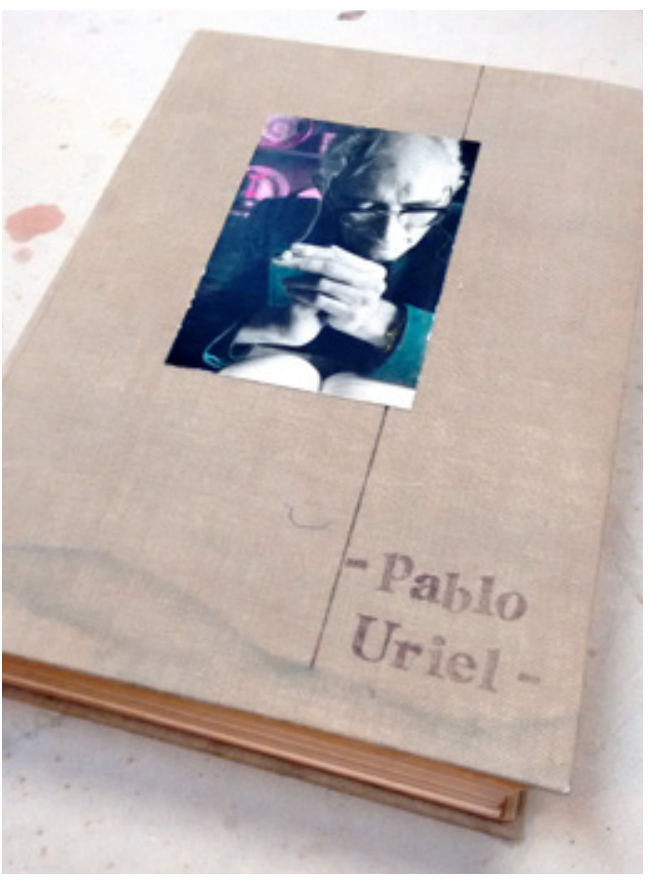

Fig. 7. Portada de la autobiografía de Pablo Uriel. Cortesía de Elena Uriel y Sento Llobell

Finalmente, la ofensiva republicana sobre Aragón conduce a una descripción de la batalla en toda su crueldad. Como médico, observa impotente la destrucción que le rodea y las reacciones ante la muerte de soldados y ciudadanos. Con la conquista republicana de la villa, Uriel es hecho prisionero, salvando milagrosamente la vida después del fusilamiento de todos los oficiales nacionales capturados. Acaba de nuevo como prisionero cerca de Valencia, donde pasará el resto de la guerra manteniendo constantemente su probidad y estoicismo ante las situaciones extremas que configuran su recorrido vital.

El volumen, en su versión integral, tiene casi 400 páginas y añade unas 25 más con documentación, entre las que se incluyen cartas dirigidas por Uriel a su familia, fotografías de la época, carnets, certificados, fotografías actuales de los espacios donde tuvieron lugar los hechos y otro material al que se hace referencia en la historia. Los objetos ocupan en este sentido un lugar especial, como depositarios de emociones en estas historias conectivas, ese papel de la "rememoria" o "mich-Gedächtnis" del que habla
Marianne Hirsch siguiendo a Aleida Assmann en el que la presencia del objeto apela al cuerpo y a los sentidos más que al lenguaje y la razón ${ }^{23}$. De este modo, la cajita de marfil labrada por un preso o el reloj recuperado del hermano fusilado son señalados por el relato y aparecen en este apéndice documental como elementos de conexión emocional con el pasado. En cierto modo, la propia historia parte de un ejercicio de memoria que, desde el ámbito familiar, se extiende al espacio público. Efectivamente, como comenta Pablo Uriel en la nota introductoria a la primera edición de sus memorias, el motivo de redactarlas surgió ante la campaña propagandística de los XXV años de paz, el intento del régimen franquista por ir sustituyendo la arcaica retórica de la Victoria que lo legitimaba por otra más amable vinculada a la idea de paz. Preocupado por la visión distorsionada de los hechos que podían recibir sus hijos, redactó unos folios mecanografiados a partir de las notas que tomó durante la guerra con el fin de que comprendieran "cuánta miseria y terror se agazapaban detrás de esa paz tan hermosa"24. En 1964 no era posible dar salida pública a esas impresiones de la guerra y el relato quedó restringido al ámbito familiar. De hecho, la primera edición del libro fue un regalo para el autor realizado hacia 1975, un ejemplar único mecanografiado, prologado y encuadernado por familiares y amigos ${ }^{25}$. Su hija Elena Uriel se ocupó de elaborar las ilustraciones que adornan el ejemplar que quedó como un tesoro de la familia (figs. 7 y 8). Unos años más tarde el libro vio la luz con un prólogo de lan Gibson y sirvió de base para la novela gráfica de Sento Llobell, coloreada de ma-

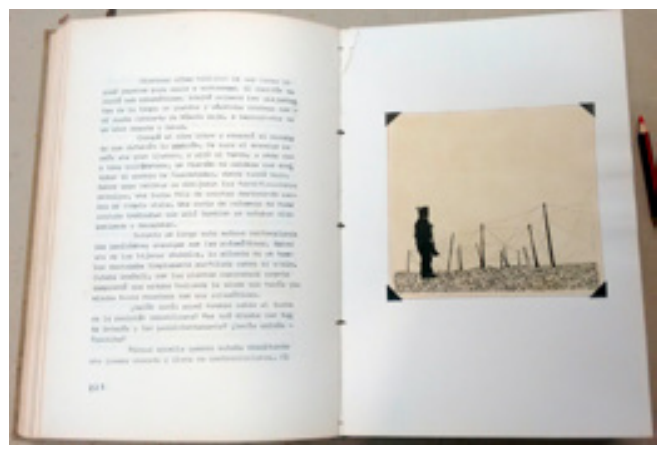

Fig. 8. Manuscrito de la autobiografía de Pablo Uriel. Cortesía de Elena Uriel y Sento Llobell 
nera sobria, con precisos y significativos golpes cromáticos, por la propia Elena Uriel26.

El equilibrio entre documento y ficción está presente en todo el proyecto. Lo esencial del relato se ajusta a las memorias de Uriel, pero también se pueden encontrar invenciones y convenciones del género que hacen la historia más asequible al lector general. Como vimos anteriormente, algunos de los objetos y documentos que aparecen en el relato encuentran su función en el despliegue narrativo, asentando el efecto de veracidad que la sostiene. Pero hay también reelaboraciones gráficas de voluntad metafórica que hacen más compleja la crónica descarnada de las experiencias de Pablo Uriel y pueden explicar algunos mecanismos del funcionamiento de la posmemoria. En un fragmento de su libro, Uriel cuenta cómo se instaló con otro oficial en la casa de una viejecita soltera, la señora Rosita, que vivía rodeada por sus objetos queridos, entre ellos unas delicadas tacitas de porcelana. Sus huéspedes intentaron convencerla de que las guardara por el peligro de que las destruyera una explosión o algún cascote, pero Rosita se negaba afirmando que ella siempre

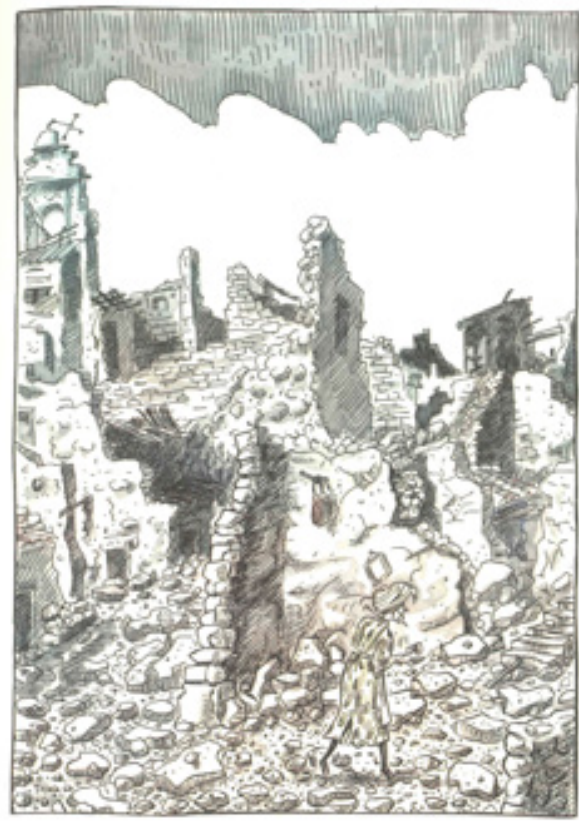

Fig. 9. Sento Llobell, "Doña Rosita en las ruinas." En Vencedor y vencido (2016)

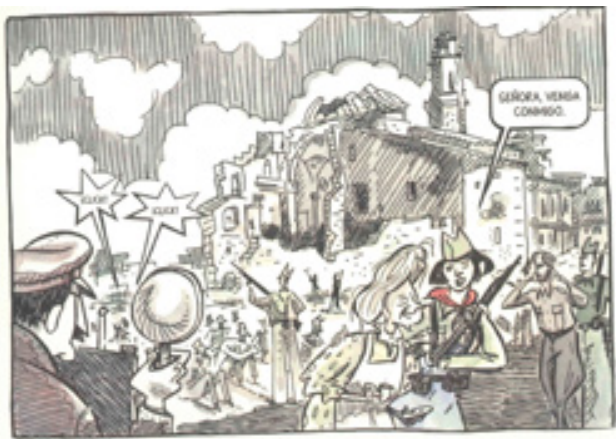

Fig. 10. Sento Llobell, "Doña Rosita y miliciana." En Vencedor y vencido (2016)

estaba en casa. Si ésta se venía abajo ella también desaparecería y por tanto todo daría lo mismo. Poco después, Uriel relata que Rosita no sobrevivió a sus primorosas tazas ${ }^{27}$. La transcripción de la anécdota al cómic por parte de Sento ofrece una brillante síntesis conceptual sobre la experiencia de la guerra. La primera viñeta del tercer volumen muestra a Rosita caminando con una taza entre las ruinas de Belchite después de la batalla. En vez de morir, como dicen las memorias, es recogida por una miliciana para desaparecer de la historia (figs. 9 y 10). Pero lo que resulta particularmente interesante es la capacidad de síntesis que elabora ese contraste conceptual en la viñeta. La fragilidad de la porcelana superviviente entre el desolado espacio de cascotes y edificios derrumbados permite que el relato gráfico se eleve sobre la anécdota concreta y ofrezca una relectura memorística del trauma capaz de mantener su potencia evocadora en el presente. Permite en suma, una entrada del lector en ese ámbito de la experiencia que se abre a una "identificación con" más que una "identificación como" 28 .

Por su parte, La promesa de Franco (Marc Weymuller, 2013) comienza con unas imágenes de una película de aficionado en súper 8 , muy borrosas, en las que apenas resulta perceptible el desmoronamiemto de un muro de una de las casas de Belchite. Un cartel recoge una frase de Borges que plantea una implícita defensa de la recuperación del pasado a través de la memoria: "La verdad histórica no es... lo que sucedió; es lo que juzgamos que sucedió". A partir de esta idea, la película despliega un dispositivo retórico muy complejo que revela la manera tensa y conflictiva 


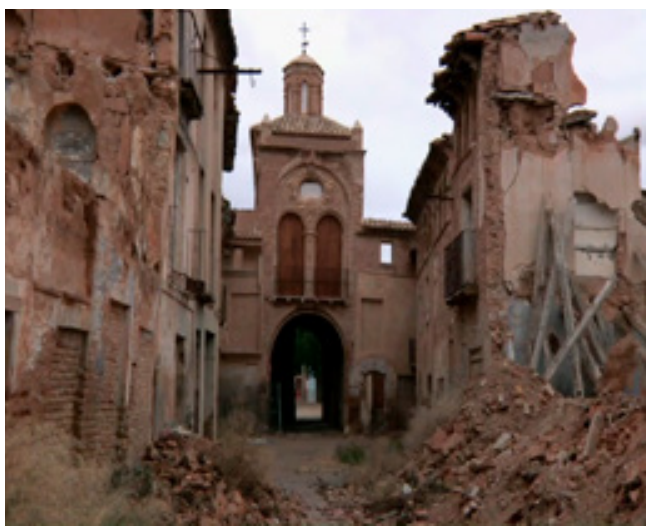

Fig. 11. Marc Weymuller, Ruinas de Belchite, imagen de La promesa de Franco (2013)

esta recuperación. El planteamiento proviene del azar: un encuentro casual de un viajero francés conduciendo por las carreteras de España que se topa con la intrigante visión de un campanario en ruinas y un pueblo del que jamás ha oído hablar. A partir de ese enigma, el cineasta comenzará su recomposición del pasado de acuerdo con la combinación de tres tipos de imágenes. Por un lado, la noticia de No-Do vista anteriormente remontada y manipulada (con efectos de ralentí y reencuadre), además de fotografías, postales y otras películas recuperadas de diversos archivos. Por otro lado, el material más importante del filme, las imágenes rodadas por el propio cineasta que tienen una elaboración particularmente compleja. Las tomas de las ruinas son importantes en la primera parte. Aparecen abandonadas, desérticas (fig. 11), compuestas en planos fijos que subrayan el estatismo del lugar y establecen un contraste con las animadas calles del pueblo nuevo. La detención del tiempo parece ser el sentido dominante en este tipo de imágenes, y esta idea se enfatiza por el uso habitual de la foto fija a lo largo del filme, a veces de manera muy interesante mediante la muestra de álbumes familiares (fig. 12).

Una técnica comparable se emplea a la hora de presentar los testimonios de los habitantes de Belchite. La cámara presentará sus rostros, pero nunca les vemos enunciando las palabras que escucharemos. Los testimonios aparecen así en la banda sonora sobre primeros planos de los habitantes del pueblo mirando a cámara o al fuera de campo, también ocupados en sus actividades

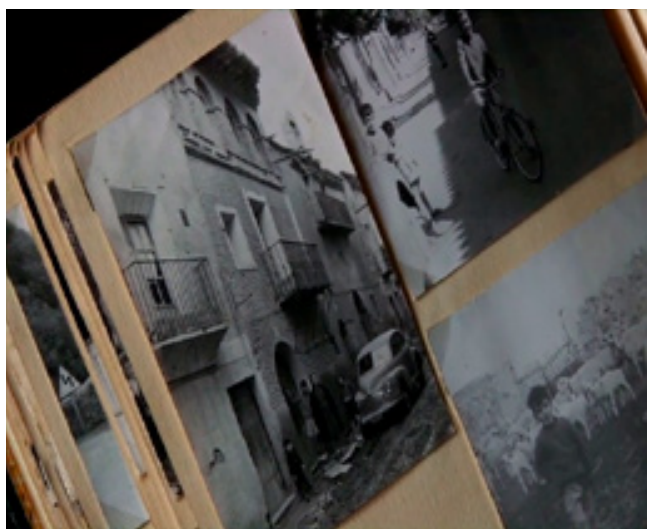

Fig. 12. Marc Weymuller, Álbum familiar, imagen de La promesa de Franco (2013)

cotidianas y, muy a menudo, superpuestas a imágenes de espacios desiertos, interiores de las casas o edificaciones, calles o plazas. Un elemento más viene a complementar el encademaniemto de los testimonios en la banda sonora. Se trata de la propia voice over del cineasta, que reflexiona de manera introspectiva sobre el sentido de su búsqueda y la incierta tarea de comprender el pasado. Hay, por lo tanto, una disociación entre la imagen del testigo y su palabra, de modo que esta reduplica su poder evocador al disociarse del momento concreto que nos muestra la pantalla. De hecho, la imagen acaba convertida casi siempre en un retrato casi estático, con los personajes metidos en sus recuerdos o mirando hacia un fuera de campo (una manera de indicar la latencia del pasado que envuelve la voz testimonial) que dota de espesor a la palabra en el momento de ser enunciada.

Pero hay un tercer tipo de imágenes que viene a condensar el auténtico valor del registro testimonial y de la elaboración de la posmemoria. Me refiero a las rodadas por el abuelo de uno de los testigos con una cámara de súper 8 de los años 60 y 70 que, como vimos, abren el filme y lo van a ir punteando esporádicamente en su desarrollo. No olvidemos que los testimonios que escuchamos no son, en la mayoría de los casos, de supervivientes de la batalla, sino de personas que eran niños en aquél momento o ni siquiera habían nacido, individuos construidos por los silencios y los rumores que existían en el pueblo, por el peso del trauma colectivo que todavía les 


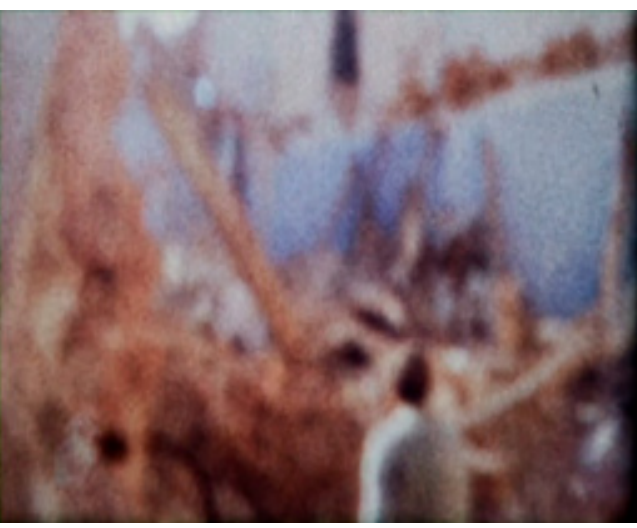

Fig. 13. Marc Weymuller, Película familiar, imagen de La promesa de Franco (2013)

divide de una manera latente. Unido a ello, el ritmo lento y contemplativo que caracteriza al documental determina que acabe por dominar un cierto cariz nostálgico en el relato ${ }^{29}$. Por este motivo, las imágenes en súper ocho que recrean situaciones cotidianas y también algún acontecimiento singular (la visita del príncipe Juan Carlos a finales de los 60, por ejemplo) plantean en su textura, en su escasa visibilidad, la densidad de la bruma que envuelve a la (pos)memoria a la hora

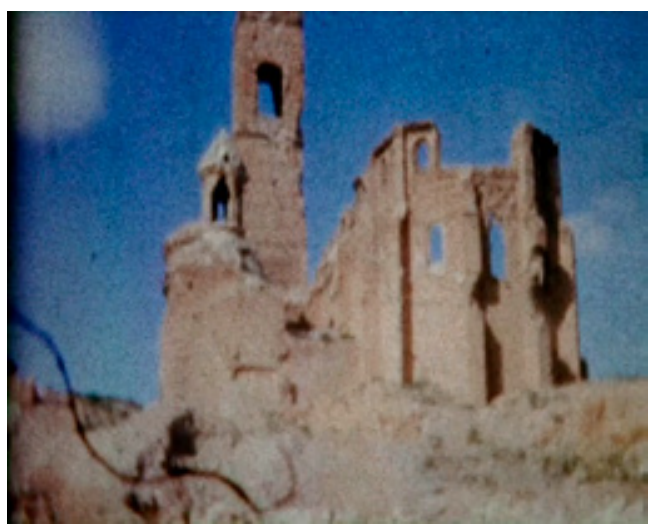

Fig. 14. Marc Weymuller, Película familiar, imagen de La promesa de Franco (2013)

de evocar los hechos del pasado (figs. 13 y 14). La descomposición y ruina del material fotoquímico que soporta las imágenes parece incidir en la dimensión fantasmagórica de la operación de la memoria que la película quiere poner en pie. Y por extensión, construyen una nueva metáfora sobre la fuerza memorística de las ruinas de Belchite, desbordando su vinculación a un acontecimiento histórico singular para entrar en una dimensión íntima y, a la vez, universal. 


\section{NOTAS}

${ }^{1}$ Véase entre otros Rafael R. Tranche y Vicente Sánchez-Biosca, El pasado es el destino: propaganda y cine del bando nacional en la Guerra Civil, Cátedra/Filmoteca Española, Madrid, 2011, p. 226. Para un recorrido detallado sobre el tema ver Stéphane Michonneau: "Ruinas de guerra e imaginario nacional bajo el franquismo" en HAL-archivesouvertes.fr (2018), https://hal.archivesouvertes.fr/hal-01686039

2 Stéphane Michonneau, Fue ayer. Belchite: un pueblo frente a la cuestión del pasado, Prensas de la Universidad de Zaragoza, Zaragoza, 2017, p. 116.

${ }^{3}$ Ángel Alcalde: "La "gesta heroica" de Belchite: construcción y pervivencia de un mito bélico franquista (1937-2007)" en Ayer, 80 (4), 2010, pp. 200-201.

${ }^{4}$ Así se afirma en la locución, por ejemplo, de las películas anarquistas Tres fechas gloriosas o Alas negras, ambas de 1938 (SIE Films) y fotografiadas por Félix Marquet. También en el noticiario 19/8 de España al día y en la antología de imágenes del noticiario dirigida al público argentino denominada Fuego en España (1938) en el que la locución afirma que el pueblo se encontraba defendido "con fortalezas subterráneas dirigidas por técnicos extraneros aprovechando las enseñanzas de la gran guerra."

${ }^{5}$ Crónica, año IX, n 409, 17 de septiembre de 1937.

6 "Un pueblo español libertado: Belchite" en Estampa, n 503, 18-09-1937, pp. 3-6.

${ }^{7}$ Eduardo Fuembuena, Guerra en Aragón, Belchite, Quinto, Teruel, Editorial Heraldo de Aragón, Zaragoza, 1938. Como muestra de esa retórica referida a las ruinas, escribe Fuembuena: "Belchite tenía así el bello final, la gloriosa apoteo- sis de sucumbir arrasado, de no volver a ser pueblo bajo el infamante trapo rojo del ejército invasor, extranjero y extranjerizado", p. 63.

${ }^{8}$ Cristina Martínez de Vega, "Francisco Martínez Gascón, Kautela. Un fotógrafo durante la Guerra civil española en Heraldo de Aragón", Revista General de Información y Documentación, 26 (2), 2016, p. 687.

${ }^{9}$ Reconstrucción, n 1, Abril 1940.

${ }^{10}$ Pedro Gómez Aparicio, "El símbolo de los dos Belchites", Ibídem, pp. 6-7

${ }^{11}$ S. Michonneau, Fue ayer..., op. cit., p. 93.

12 Ver Rafael R. Tranche y Vicente Sánchez-Biosca, No-Do: el tiempo y la memoria, Cátedra, Madrid, 2001, p. 259.

${ }^{13} \mathrm{El}$ título completo de la película es Informe general sobre algunas cuestiones de interés para una proyección pública.

${ }^{14}$ Ver Michonneau, Fue ayer... , pp. 161-163.

${ }^{15}$ Ricard Vinyes, "Sobre las ruina y su relato. Lo que vemos, lo que sabemos, lo que hacemos" Acompañar la ruina en http://memoriasenred.es/foro vestigios/

${ }^{16}$ Para un recorrido por este asunto véase Stéphane Michonneau, "Belchite ou l'impossible dark tourism de la guerre civil espagnole" en Mémoires en jeu, $\mathrm{n}^{\circ}$ 3, mayo 2017, p. 55-62.

17 Sergio del Molino, "Barones, bombas y porno en el pueblo viejo de Belchite" http://www.aisge.es/belchiteun-escenario-de-cine

${ }^{18}$ Marianne Hirsch, La generación de la posmemoria: escritura y cultura visual del Holocausto. PanCrítica, Madrid, 2015, p. 19.

${ }^{19}$ Para una introducción a este tema pueden consultarse José Carlos Rueda
Laffond, "Memorias proyectadas, tránsitos simbólicos y cómic contemporáneo" en Laia Quílez y J. Carlos Rueda Laffond (eds.), Posmemoria de la guerra civil y el franquismo, Comares, Granada, 2017, pp. 177-194 y también Benoît Mitaine, "Au nom du père ou les "autobiographies" de ceux que ne dessinent pas" en Viviane Alary et al. (eds.), Autobio-graphismes. Bande dessinée et représentation de soi, éditions Georg-L'Équinoxe, Chêne-Bourg, 2015, pp. 171-194.

${ }^{20}$ Benoît Mitaine, Ibídem, p. 173.

${ }^{21}$ La obra apareció incialmente en tres entregas tituladas: Un médico novato (2013), Atrapado en Belchite (2015) y Vencedor y vencido (2016). Una edición reunida y en un formato de página algo más grande se publicó en 2016 bajo el título de Dr. Uriel (ed. Astiberri).

22 Pablo Uriel, No se fusila en domingo. Pre-textos, Valencia, 2008

${ }^{23}$ Marianne Hirsch, La generación de la posmemoria, p. 281

${ }^{24}$ Pablo Uriel, No se fusila en domingo..., p. 17.

${ }^{25}$ Elena Uriel, "Nota a la presente edición" Ibídem, p. 21

${ }^{26}$ Elena Galán Fajardo y José Carlos Rueda Laffond, "Those wars are also my war: An approach to practices of postmemory in the contemporary Spanish comic" Catalan Journal of Communication and Cultural Studies, v. 8, $n^{\circ} 1$, 2016, p. 73

${ }^{27}$ Pablo Uriel, No se fusila..., p. 330

${ }^{28}$ Marianne Hirsch, La generación de la posmemoria..., p. 122.

29 Pascale Thibaudeau, "Filmer les ruines et faire parler le présent: $L a$ Promesse de Franco de Marc Weymuller." Conserveries mémorielles, 20, 2017, http://journals.openedition.org/ $\mathrm{cm} / 2492$ 
Las ruinas de Belchite: crónica, memoria, posmemoria y fantasmagoría

\section{REFERENCIAS}

Alcalde, Ángel. 2010. "La "gesta heroica" de Belchite: construcción y pervivencia de un mito bélico franquista (1937-2007)." Ayer 80, no. 4: 200-201

Fuembuena, Eduardo. 1938. Guerra en Aragón, Belchite, Quinto, Teruel. Zaragoza: Editorial Heraldo de Aragón.

Galán Fajardo, Elena, and José Carlos Rueda Laffond. 2016. "Those wars are also my war: An approach to practices of postmemory in the contemporary Spanish comic." Catalan Journal of Communication and Cultural Studies 8, no. 1: 73. https://doi.org/10.1386/cjcs.8.1.63_1

Gómez Aparicio, Pedro. 1940. “El símbolo de los dos Belchites." Reconstrucción (Abril): 6-7.

Hirsch, Marianne. 2015. La generación de la posmemoria: escritura y cultura visual del Holocausto. Madrid: PanCrítica.

Martínez de Vega, Cristina. 2016. "Francisco Martínez Gascón, Kautela. Un fotógrafo durante la Guerra civil española en Heraldo de Aragón." Revista General de Información y Documentación 26, no. 2: 687.

Michonneau, Stéphane. 2017. "Belchite ou l'impossible dark tourism de la guerre civil espagnole." Mémoires en jeu 3 (Mayo): 55-62.

Michonneau, Stéphane. 2017. Fue ayer. Belchite: un pueblo frente a la cuestión del pasado. Zaragoza: Prensas de la Universidad de Zaragoza.

Michonneau, Stéphane. 2018. "Ruinas de guerra e imaginario nacional bajo el franquismo." In
HAL-archives-ouvertes.fr . https://hal.archivesouvertes.fr/hal-01686039

Mitaine, Benoît. 2015. "Au nom du père ou les "autobiographies" de ceux que ne dessinent pas." In Autobio-graphismes. Bande dessinée et représentation de soi, edited by Viviane Alary et al., 171-194. Chêne-Bourg: éditions Georg-L'Équinoxe.

Molino, Sergio del. 2017. "Barones, bombas y porno en el pueblo viejo de Belchite."

Rueda Laffond, José Carlos. 2017. "Memorias proyectadas, tránsitos simbólicos y cómic contemporáneo." In Posmemoria de la guerra civil y el franquismo, edited by Laia Quílez, and José Carlos Rueda Laffond, 177-194. Granada: Comares.

Thibaudeau, Pascale. 2017. "Filmer les ruines et faire parler le présent: La Promesse de Franco de Marc Weymuller." Conserveries mémorielles 20. http://journals.openedition.org/cm/2492

Tranche Rafael R., and Vicente Sánchez-Biosca. 2001. No-Do: el tiempo y la memoria. Madrid: Cátedra, Madrid, 2001.

Tranche, Rafael R., and Vicente Sánchez-Biosca. 2011. El pasado es el destino: propaganda y cine del bando nacional en la Guerra Civil. Madrid: Cátedra/Filmoteca Española.

Uriel, Pablo. 2008. No se fusila en domingo. Valencia: Pre-textos.

Vinyes, Ricard. "Sobre las ruinas y su relato. Lo que vemos, lo que sabemos, lo que hacemos" Acompañar la ruina. http://memoriasenred.es/ foro vestigios/ 